\title{
Cytokines induce endoplasmic reticulum stress in human, rat and mouse beta cells via different mechanisms
}

\author{
Flora Brozzi ${ }^{1}$ - Tarlliza R. Nardelli ${ }^{1}$ - Miguel Lopes ${ }^{1} \cdot$ Isabelle Millard $^{1}$ • \\ Jenny Barthson ${ }^{1} \cdot$ Mariana Igoillo-Esteve $^{1} \cdot$ Fabio A. Grieco ${ }^{1}$. Olatz Villate ${ }^{1}$. \\ Joana M. Oliveira ${ }^{1} \cdot$ Marina Casimir $^{1}$ - Marco Bugliani ${ }^{2} \cdot$ Feyza Engin $^{3}$. \\ Gökhan S. Hotamisligil ${ }^{4}$ - Piero Marchetti ${ }^{2}$ - Decio L. Eizirik ${ }^{1}$
}

Received: 23 February 2015 / Accepted: 29 May 2015 /Published online: 23 June 2015

(C) Springer-Verlag Berlin Heidelberg 2015

\begin{abstract}
Aims/hypothesis Proinflammatory cytokines contribute to beta cell damage in type 1 diabetes in part through activation of endoplasmic reticulum (ER) stress. In rat beta cells, cytokineinduced ER stress involves NO production and consequent inhibition of the ER $\mathrm{Ca}^{2+}$ transporting ATPase sarco/ endoplasmic reticulum $\mathrm{Ca}^{2+}$ pump 2 (SERCA2B). However, the mechanisms by which cytokines induce ER stress and apoptosis in mouse and human pancreatic beta cells remain unclear. The purpose of this study is to elucidate the role of ER stress on cytokine-induced beta cell apoptosis in these three species and thus solve ongoing controversies in the field.

Methods Rat and mouse insulin-producing cells, human pancreatic islets and human EndoC- $\beta \mathrm{H} 1$ cells were exposed to the cytokines IL- $1 \beta$, TNF- $\alpha$ and IFN- $\gamma$, with or without NO inhibition. A global comparison of cytokine-modulated gene expression in human, mouse and rat beta cells was also
\end{abstract}

Flora Brozzi and Tarlliza R. Nardelli contributed equally to the study.

Electronic supplementary material The online version of this article (doi:10.1007/s00125-015-3669-6) contains peer-reviewed but unedited supplementary material, which is available to authorised users.

Decio L. Eizirik

deizirik@ulb.ac.be

$1 \quad$ ULB-Center for Diabetes Research, Universitè Libre de Bruxelles (ULB), Route de Lennik, 808-CP618, 1070 Brussels, Belgium

2 Department of Clinical and Experimental Medicine, Islet Laboratory, University of Pisa, Pisa, Italy

3 Department of Biomolecular Chemistry, University of Wisconsin-Madison School of Medicine and Public Health, Madison, WI 53706, USA

4 Department of Genetics and Complex Diseases, Sabri Ülker Center, Harvard School of Public Health, Boston, MA 02115, USA performed. The chemical chaperone tauroursodeoxycholic acid (TUDCA) and suppression of C/EBP homologous protein (CHOP) were used to assess the role of ER stress in cytokineinduced apoptosis of human beta cells.

Results NO plays a key role in cytokine-induced ER stress in rat islets, but not in mouse or human islets. Bioinformatics analysis indicated greater similarity between human and mouse than between human and rat global gene expression after cytokine exposure. The chemical chaperone TUDCA and suppression of CHOP or c-Jun N-terminal kinase (JNK) protected human beta cells against cytokine-induced apoptosis.

Conclusions/interpretation These observations clarify previous results that were discrepant owing to the use of islets from different species, and confirm that cytokine-induced ER stress contributes to human beta cell death, at least in part via JNK activation.

Keywords Apoptosis · c-Jun N-terminal kinase · Cytokines · ER stress · Human islets · Type 1 diabetes

$\begin{array}{ll}\text { Abbreviations } \\ \text { ATF3 } & \text { Activating transcription factor } 3 \\ \text { ATF4 } & \text { Activating transcription factor } 4 \\ \text { ATF6 } & \text { Activating transcription factor } 6 \\ \text { BIP } & \text { Binding immunoglobulin protein } \\ \text { CHOP } & \text { C/EBP homologous protein } \\ \text { eIF2 } & \text { Eukaryotic initiation factor } 2 \\ \text { ER } & \text { Endoplasmic reticulum } \\ \text { H } \beta C L & \text { Human beta cell line EndoC- } \beta \text { H1 } \\ \text { iNOS } & \text { Inducible NO synthase } \\ \text { IRE1 } \alpha & \text { Inositol-requiring protein } 1 \alpha \\ \text { JNK } & \text { c-Jun N-terminal kinase } \\ \text { L-NMMA } & N^{\mathrm{G}} \text {-methyl-L-arginine }\end{array}$




$\begin{array}{ll}\text { PERK } & \begin{array}{l}\text { Protein kinase RNA-like endoplasmic } \\ \text { reticulum kinase }\end{array} \\ \text { SERCA2B } & \text { Sarco/endoplasmic reticulum } \mathrm{Ca}^{2+} \text { pump 2 } \\ \text { siC } & \text { siRNA control } \\ \text { si(RNA) } & \text { Small interfering (RNA) } \\ \text { TUDCA } & \text { Tauroursodeoxycholic acid } \\ \text { UPR } & \text { Unfolded protein response } \\ \text { XBP1(s) } & \text { X-box binding protein 1 (spliced) }\end{array}$

\section{Introduction}

Type 1 diabetes is characterised in most cases by islet inflammation (insulitis) and consequent dysfunction and death of pancreatic beta cells. Locally produced proinflammatory cytokines, such as IL- $1 \beta$, TNF- $\alpha$ and IFN- $\gamma$, contribute to beta cell apoptosis [1]. One important mechanism by which cytokines contribute to beta cell death is via induction of endoplasmic reticulum (ER) stress and the consequent triggering of the unfolded protein response (UPR) [2]. The canonical UPR is mediated through activation of three ER transmembrane proteins: inositol-requiring protein $1 \alpha(\operatorname{IRE} 1 \alpha)$, protein kinase RNA-like endoplasmic reticulum kinase (PERK) and activating transcription factor 6 (ATF6) [3-5]. These proteins detect the accumulation of unfolded proteins in the ER lumen and activate mechanisms to restore its homeostasis [3-5]. In unresolved ER stress, persistent stimulation of the UPR triggers apoptosis via activation of C/EBP homologous protein (CHOP), c-jun N-terminal kinase (JNK), death protein 5 (DP5) and other proapoptotic signals $[6,7]$.

Markers of the UPR are expressed in inflamed islets in vivo, in both samples from NOD mice $[8,9]$ and pancreatic sections of individuals with type 1 diabetes [10]. ER stress is also induced when pancreatic islets or purified beta cells are exposed in vitro to cytokines $[2,11]$. Importantly, in both NOD mice and individuals with type 1 diabetes the beta cells fail to sustain components of the adaptive UPR, contributing to their demise [9]. The mechanisms by which cytokines trigger ER stress remain under debate. Initial studies indicated that IL- $1 \beta+$ IFN- $\gamma$ causes ER $\mathrm{Ca}^{2+}$ depletion and apoptosis in rat beta cells and rat insulin-producing INS-1E cells via production of $\mathrm{NO}$ and the consequent inhibition of the sarco/ endoplasmic reticulum $\mathrm{Ca}^{2+}$ pump 2 (SERCA2B) [11]. On the other hand, it was suggested that IL- $1 \beta+$ TNF- $\alpha+$ IFN- $\gamma$ induces X-box binding protein 1 (XBP1) splicing and PERK/eukaryotic initiation factor 2 (eIF2 $\alpha$ ) phosphorylation in mouse islets or MIN6 cells independently of NO production [12]. It is not clear whether these discrepant results reflect the use of different species (rat or mice). Furthermore, it should be determined which of the two animal models, if either, reproduces the patterns of cytokine-induced ER stress in human islets, the 'gold standard' to understand human disease.

In order to answer this question, we exposed rat and mouse insulin-producing cells, human pancreatic islets and the human beta cell line EndoC- $\beta \mathrm{H} 1$ (H $\beta C L)$ to cytokines, with or without concomitant inhibition of NO production. The data obtained suggest a key role for NO in cytokine-induced ER stress in rat islets, but not in mouse or human islets. Furthermore, a systematic comparison of global gene expression obtained in human, rat or mouse pancreatic islets after cytokine exposure indicates a greater similarity between human and mouse gene expression than between human and rat. In spite of these differences, we observed that cytokineinduced ER stress is also important for human beta cell death. Thus, the chemical chaperone tauroursodeoxycholic acid (TUDCA), previously shown to mitigate ER stress [13] and protect rat and mouse beta cells against ER stress-induced apoptosis [9], or a small interfering (si)RNA blocking CHOP, a key executioner of ER stress-mediated apoptosis $[2,14]$, partially protected human islet cells against cytokine-induced apoptosis. Finally, we identified JNK as a crucial downstream mediator leading to human beta cell apoptosis.

These observations clarify previous discrepant results in the field, which are due to the use of islets from different species, and suggest that cytokine-induced ER stress, at least in part via JNK activation, contributes to human beta cell death.

\section{Methods}

Culture of human islets and $\mathrm{H} \beta C \mathrm{CL}$, INS-1E and MIN6 cells Human islets from 12 non-diabetic donors (electronic supplementary material [ESM] Table 1) were isolated in Pisa as described [15]. Beta cell purity (immunofluorescence for insulin) was $50 \pm 4 \%$. The islets were cultured in M199 culture medium containing $5.5 \mathrm{mmol} / \mathrm{l}$ glucose and sent to Brussels, Belgium, within 1-5 days of isolation, where they were dispersed and cultured in Ham's F-10 medium containing $6.1 \mathrm{mmol} / 1$ glucose as described $[16,17]$. Insulin-producing $\mathrm{H} \beta C L$ cells, kindly provided by R. Scharfmann, University of Paris, France [18], were cultured as previously described [19] (see ESM Methods for details). Rat insulin-producing INS-1E cells, kindly provided by C. Wollheim, University of Geneva, Switzerland, were cultured in RPMI 1640 GlutaMAX-I medium (Invitrogen Life Technologies, Paisley, UK) [20]. Mouse insulin-producing MIN6 cells, kindly provided by S. Lenzen, Hannover Medical School, Germany, were cultured in DMEM containing $4.5 \mathrm{~g} / \mathrm{l}$ glucose and $4 \mathrm{mmol} / \mathrm{l}$ L-glutamine supplemented with $100 \mathrm{U} / \mathrm{ml}$ penicillin and $100 \mu \mathrm{g} / \mathrm{ml}$ streptomycin, $70 \mu \mathrm{mol} / 12$-mercaptoethanol and 
$15 \%$ FBS. All cell lines used are mycoplasma free, and are checked on a monthly basis.

Cell treatment and NO measurement The inducible NO synthase (iNOS) blocker $N^{\mathrm{G}}$-methyl-L-arginine (L-NMMA; Sigma, Steinheim, Germany) was dissolved in water and used in INS-1E and MIN6 cells at $1.0 \mathrm{mmol} / \mathrm{l}$ and in human islets at $5.0 \mathrm{mmol} / \mathrm{l}$, concentrations previously shown to prevent cytokine-induced NO production [11, 12, 21, 22]. The chemical chaperone TUDCA (Calbiochem, Darmstadt, Germany) was dissolved in water and used at $62 \mu \mathrm{mol} / 1$ and $125 \mu \mathrm{mol} / \mathrm{l}$, based on dose-response experiments (data not shown).

The following cytokine concentrations were used, based on previous experiments performed by our group [16, 23-25]: recombinant human IL-1 $\beta$ (R\&D Systems, Abingdon, UK) $10 \mathrm{U} / \mathrm{ml}$ for INS-1E or $50 \mathrm{U} / \mathrm{ml}$ for human islets, MIN6 and $\mathrm{H} \beta C L$ cells; recombinant rat IFN- $\gamma$ (R\&D Systems) $100 \mathrm{U} / \mathrm{ml}$ for INS-1E or $1,000 \mathrm{U} / \mathrm{ml}$ for MIN6; human IFN- $\gamma$ (Peprotech, London, UK) $1,000 \mathrm{U} / \mathrm{ml}$ for human islets or $\mathrm{H} \beta \mathrm{CL}$ cells; recombinant murine TNF- $\alpha$ (Innogenetics, Gent, Belgium) $100 \mathrm{U} / \mathrm{ml}$ for INS-1E and 1,000 U/ml for all the other cell types. Lower cytokine concentrations and shorter time intervals were used in the INS-1E experiments because rat beta cells are more sensitive to cytokine-induced damage than mouse and human beta cells $[22,26]$. Culture medium was collected for nitrite determination (nitrite is a stable product of NO oxidation) by the Griess method [27, 28]. The detailed protocol for the Griess method in H $\beta C L$ cells is described in ESM Methods.

RNA interference The siRNAs used are described in ESM Methods. The optimal conditions of siRNA transfection (30 nmol/1) were previously established [16, 29]. Cells were transfected using Lipofectamine RNAiMAX (Invitrogen) [29, 30]. AllStars Negative Control siRNA (Qiagen, Venlo, the Netherlands) was used as negative siRNA control (siC); it does not affect beta cell gene expression or insulin secretion in INS-1E cells, primary rat or human islet cells $[29,30]$ or in $\mathrm{H} \beta \mathrm{CL}$ cells (see ESM Methods).

Assessment of cell viability The percentages of viable, apoptotic and necrotic cells were determined after 15 min incubation with propidium iodide ( $5 \mu \mathrm{g} / \mathrm{ml}$; Sigma-Aldrich) and Hoechst dye 33342 ( $5 \mu \mathrm{g} / \mathrm{ml}$; Sigma-Aldrich). A minimum of 600 cells were counted for each experimental condition by two independent observers, one of whom was unaware of sample identity. This fluorescence assay for single cells is quantitative and has been validated by systematic comparisons against electron microscopy observations, ladder formation and caspase 3/9 activation [16, 31-33].

Messenger RNA extraction and real-time PCR Poly $(\mathrm{A})^{+}$ mRNA was isolated from cultured cells using the Dynabeads
mRNA Direct kit (Invitrogen) and reverse transcribed as previously described $[34,35]$. The real-time PCR amplification reactions were done using iQ SYBR Green Supermix (BioRad Laboratories, Temse, Belgium) and the concentration of the gene of interest was calculated using the standard curve method $[34,36]$. Gene expression values were corrected by the housekeeping genes $\beta$-actin and Gapdh, the expression of which is not modified in these cells by cytokine treatment $[16$, 37] and normalised by the highest value or as indicated in the figure legends. The primers used in this study are described in ESM Table 2.

Western blot Cells were washed with cold PBS and lysed using Laemmli sample buffer $(60 \mathrm{mmol} / 1$ Tris $\mathrm{pH} 6.8,10 \%$ Glycerol, $1 \%$ SDS, $0.001 \%$ blue Bromophenol and 5\% $\beta$-mercaptoethanol). Total protein was extracted and immunoblotted with the specific antibodies for the protein of interest as described [16]. The antibodies used are described in ESM Table 3.

Ethics statement Human islet collection and handling were approved by the local ethics committee in Pisa, Italy. Male Wistar rats were housed and used according to the guidelines of the Belgian Regulations for Animal Care. All experiments were approved by the local ethics committee.

Statistical analysis Data are expressed as mean \pm SEM. A significant difference between experimental conditions was assessed by one-way ANOVA followed by a paired Student's $t$ test with Bonferroni correction. A value of $p<0.05$ was considered statistically significant. Information on the comparative global analysis of human, rat and mouse datasets is provided in ESM Methods.

\section{Results}

Rat INS-1E cells and mouse MIN6 cells respond similarly to cytokines compared with their respective primary counterparts, i.e. rat/mouse islet cells $[11,12,38]$ or purified beta cells $[11,14,39]$. These cells were thus used for the initial comparisons with human islets exposed to cytokines with or without concomitant treatment with the iNOS blocker L-NMMA (Fig. 1 and ESM Fig. 1). Cytokine-induced NO production was similar in INS-1E cells and human islets (ESM Fig. 1a, d), while MIN6 cells showed lower nitrite production (ESM Fig. 1b, c). Interestingly, cytokines did not induce iNOS expression or $\mathrm{NO}$ production by $\mathrm{H} \beta \mathrm{CL}$ cells in the experimental protocol used (ESM Fig. 1e, f); thus the iNOS blocker was not used in these cells. The iNOS blocker L-NMMA inhibited NO production in rat, mouse and human cells (ESM Fig. 1a-d).

Preventing NO formation decreased cytokine-induced beta cell death in rat but not in mouse or human cells (MIN6 cells 
were studied after $24 \mathrm{~h}$ and $48 \mathrm{~h}$ of cytokine exposure) (Fig. 1a-d). Blocking NO formation induced a small but significant increase in cell death in human islet cells exposed to IL- $1 \beta+$ TNF- $\alpha+$ IFN- $\gamma$ (Fig. 1d). The H $\beta C L$ cells were treated with different combination of cytokines and apoptosis was assayed in the presence of different concentrations of FBS $(0 \%, 1 \%$ and $2 \%$; ESM Fig. 2$)$. At higher FBS concentrations, apoptosis was lower in control cells but cytokine-induced apoptosis was not affected. The $2 \%$ FBS culture condition was therefore chosen for the subsequent experiments in which $\mathrm{H} \beta \mathrm{CL}$ cells were exposed to cytokines. Cytokine-induced apoptosis in $\mathrm{H} \beta \mathrm{CL}$ cells (that do not produce $\mathrm{NO}$ ) confirmed that, under the experimental conditions used, NO is not required for human beta cell death (Fig. 1e). IL-1 $\beta$ alone neither induced apoptosis in $\mathrm{H} \beta \mathrm{CL}$ cells (Fig. 1e) nor induced iNOS
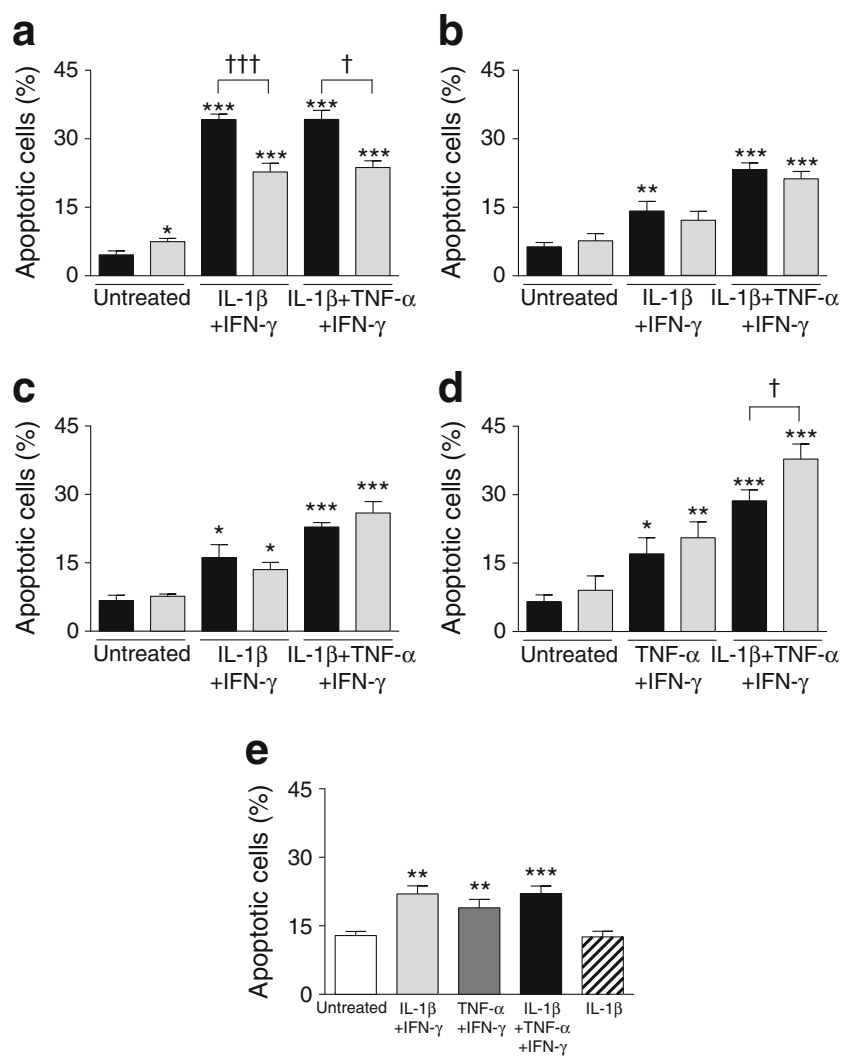

Fig. 1 Cytokine-induced apoptosis depends on NO production in rat INS-1E cells, but not in mouse MIN6 cells, human islet cells or $\mathrm{H} \beta \mathrm{CL}$ cells. INS-1E cells (a), MIN6 cells $(\mathbf{b}, \mathbf{c})$ and human islet cells $(\mathbf{d})$ were left untreated or treated with cytokines (as indicated), alone (black bars, a-d) or in combination with $1 \mathrm{mmol} / \mathrm{l}(\mathbf{a}-\mathbf{c})$ or $5 \mathrm{mmol} / \mathrm{l}$ (d) of L-NMMA (grey bars). The $\mathrm{H} \beta \mathrm{CL}$ cells (e) were treated with IL- $1 \beta+\mathrm{IFN}-\gamma$ (light grey bar), TNF- $\alpha+$ IFN- $\gamma$ (dark grey bar), IL- $1 \beta+$ TNF- $\alpha+$ IFN- $\gamma$ (black bar) or IL-1 $\beta$ alone (hatched bar). Apoptosis was evaluated after $24 \mathrm{~h}$ treatment in INS-1E and MIN6 cells (a, b) and after $48 \mathrm{~h}$ in MIN6 (c), human islet cells (d) and H $\beta C L$ cells $(\mathbf{e}) .{ }^{*} p<0.05,{ }^{* *} p<0.01$ and $* * * p<0.001$ vs untreated without L-NMMA; ${ }^{\dagger} p<0.05$ and ${ }^{\dagger \dagger} p<0.001$ as indicated by the bars; one-way ANOVA followed by Student's paired $t$ test with Bonferroni correction. Data shown are means \pm SEM of 3-12 independent experiments expression or NO production compared with controls (ESM Fig. 1e, f).

As previously described, combinations of two or three cytokines block SERCA2B expression in rat beta cells and INS1E cells [11] (data not shown) and induced a significant increase in the expression of the ER stress markers Chop, activating transcription factor 4 (Atf4), binding immunoglobulin protein (Bip; also known as HSPA5) and Xbpls (ESM Fig. 3). These cytokine effects were prevented by blocking iNOS (ESM Fig. 3). In mouse MIN6 cells the induction of most markers of the UPR (i.e. Atf4, Bip and Xbp1s) after both 24 and $48 \mathrm{~h}$ of cytokine exposure were less marked than in rat cells (compare ESM Fig. 4b-d, f-h with ESM Fig. 3b-d). The only UPR marker clearly upregulated by combinations of two or three cytokines and inhibited by the iNOS blocker was Chop (ESM Fig. 4a, e).

For human islets we used the combination of TNF- $\alpha+$ IFN- $\gamma$, which induces a marked ER stress activation [14], and also a combination of three cytokines, namely IL-1 $\beta$, TNF- $\alpha$ and IFN- $\gamma$. The combination TNF- $\alpha+$ IFN- $\gamma$ induced
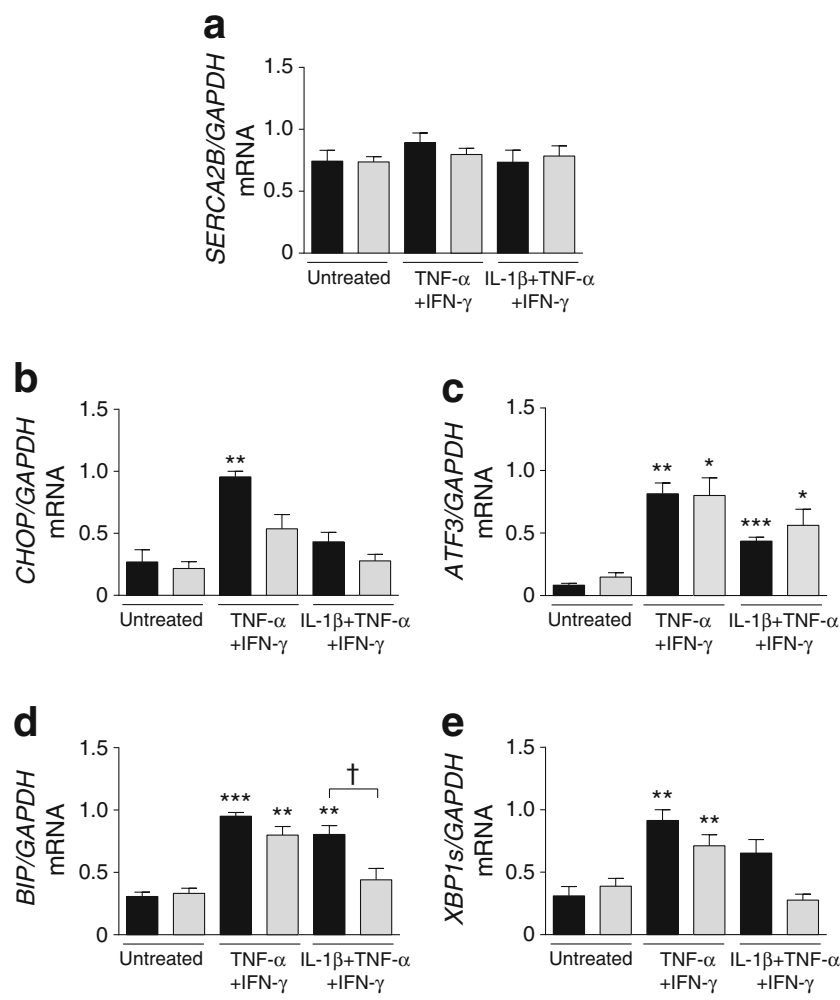

Fig. 2 SERCA2B and ER stress marker expression in human islets. Human islet cells were left untreated or treated with cytokines (as indicated), alone (black bars) or in combination with $5 \mathrm{mmol} / \mathrm{l}$ of L-NMMA (grey bars). The expression of $\operatorname{SERCA2B}(\mathbf{a}), C H O P(\mathbf{b}), A T F 3(\mathbf{c}), B I P(\mathbf{d})$ and $X B P 1 s$ (e) was assessed by RT-PCR after $48 \mathrm{~h}$ of treatment and corrected for the housekeeping gene $G A P D H .{ }^{*} p<0.05, * * p<0.01$ and $* * * p<0.001$ vs untreated without L-NMMA; ${ }^{\dagger} p<0.05$ as indicated by the bar; one-way ANOVA followed by Student's paired $t$ test with Bonferroni correction. Data shown are means \pm SEM of five to six independent experiments 
expression of UPR markers (Fig. 2b-e), without modifying SERCA2B (also known as ATP2A2) mRNA expression (Fig. 2a). These cytokines induced negligible NO formation (ESM Fig. 1d), and L-NMMA did not prevent TNF- $\alpha+$ IFN- $\gamma$-mediated activating transcription factor 3 (ATF3), $B I P$ or $X B P 1 s$ mRNA induction (Fig. 2b-e). There was, however, a small non-significant trend for a decrease in $C H O P$ mRNA expression under these experimental conditions. The combination of IL- $1 \beta+\mathrm{TNF}-\alpha+$ IFN- $\gamma$ induced a greater than tenfold increase in nitrite accumulation in the human islets (ESM Fig. 1d), but induced a less marked expression of UPR markers (Fig. 2b-e); BIP was the only marker with expression significantly decreased by L-NMMA (Fig. 2d). As BIP is a crucial chaperone for cell defence against ER stress $[40,41]$, this finding may explain why blocking NO increased IL- $1 \beta+$ TNF- $\alpha+$ IFN- $\gamma$-induced human islet cell death (Fig. 1d). The concentration of L-NMMA used to prevent cytokine-induced NO formation by human islets is not toxic on its own to human pancreatic beta cells (Fig. 1d and Eizirik et al [22]). We cannot, however, exclude some toxicity of L-NMMA when combined with the three cytokines IL-1 $\beta+$ TNF- $\alpha+$ IFN- $\gamma$ in human islets (Fig. 1d) or when used alone in INS-1E cells (Fig. 1a).

In line with the human islet data, exposure of $\mathrm{H} \beta C L$ cells to different cytokine combinations increased expression of the UPR markers CHOP, ATF3, XBP1s and phospho-eIF2 $\alpha$ (Fig. 3) and led to a non-significant trend for increased BIP expression (Fig. 3e, i), without affecting SERCA2B mRNA and protein expression (Fig. 3a, b). Exposure of $\mathrm{H} \beta C L$ cells to IL- $1 \beta$ alone did not increase the ER stress markers tested (Fig. 3c-j).

In order to obtain a broader evaluation of the impact of cytokine exposure on primary human or rodent islet cells, we made a global comparison of cytokine-modulated gene expression in human and mouse islets, and in FACS-purified rat beta cells based on previously published microarray and RNA sequencing data [17, 42-45]. There was an overall higher ranking similarity between human and mouse gene expression than between human and rat gene expression for both up- and downregulated genes (ESM Fig. 5a, b), which may, in part, be due to the fact that we analysed human and mouse islets against pure rat beta cells. In order to confirm the validity of the analysis, the three human datasets were compared with each other (ESM Fig. 6a, b), and showed greater similarity than between the human and rat or mouse datasets. An alternative analysis is presented in ESM Table 4. In all datasets, a number of differentially expressed genes (up- and downregulated) were selected, following criteria of $p<0.05$ and fold change $>2$ (or $<0.5$ in the case of downregulation). The significance of the similarity (i.e. number of common genes) of the selection in two datasets was estimated, and in all cases (except HC3 in the downregulation case) a greater significance was found between human and mouse than a

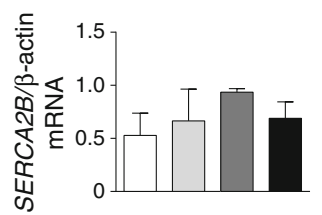

b
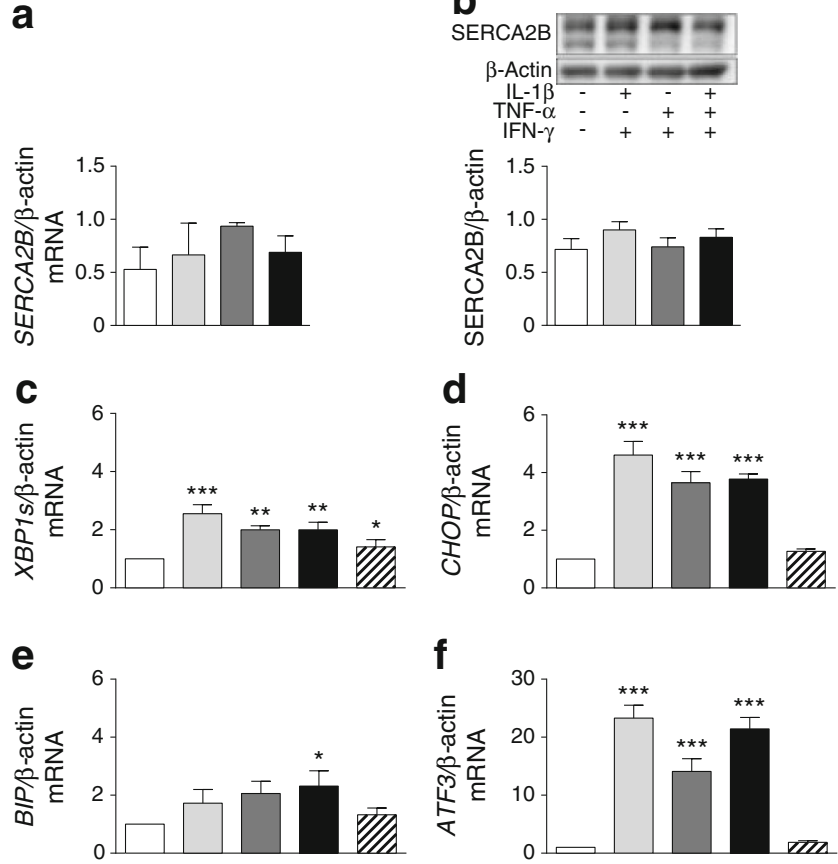

g

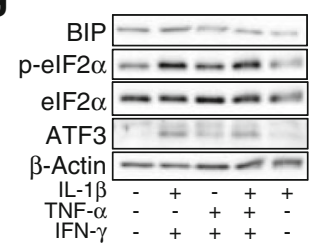

h
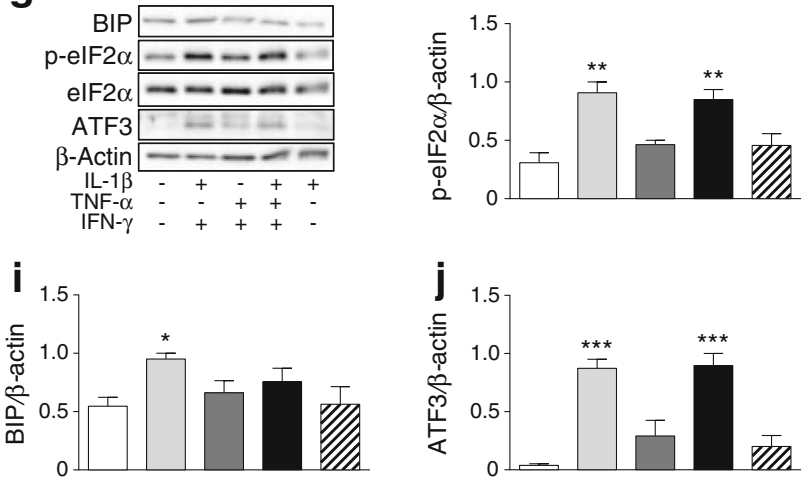

Fig. $3 S E R C A 2 B$ and ER stress marker expression in $\mathrm{H} \beta C L$ cells. $\mathrm{H} \beta \mathrm{CL}$ cells were left untreated (white bars) or were treated with IL- $1 \beta+$ IFN- $\gamma$ (light grey bars), TNF- $\alpha+$ IFN- $\gamma$ (dark grey bars), IL$1 \beta+$ TNF- $\alpha+$ IFN- $\gamma$ (black bars) and IL- $1 \beta$ alone (hatched bars) for $48 \mathrm{~h}$. The expression of SERCA2B was assessed by RT-PCR (a) and western blot (b). One representative blot and the densitometric measurement of $n=4$ are shown (b). The mRNA expression of XBP1s (c), CHOP (d), BIP (e) and ATF3 (f) was assessed by RT-PCR. The values are expressed as fold change compared with the control $(\mathbf{c}-\mathbf{f})$. The expression levels of phospho-eIF2 $\alpha(\mathbf{g}, \mathbf{h})$, BIP $(\mathbf{g}, \mathbf{i})$ and ATF3 $(\mathbf{g}, \mathbf{j})$ were assessed by western blot. One representative blot and the densitometric measurement of $n=3-4$ are shown $(\mathbf{g}-\mathbf{j})$. Both western blot and RT-PCR were corrected for the housekeeping gene $\beta$-actin and the western blot data were normalised by the highest value. $* p<0.05, * * p<0.01$ and $* * * p<0.001$ vs untreated; one-way ANOVA followed by Student's paired $t$ test with Bonferroni correction. Data shown are means $\pm \mathrm{SEM}$ of three to four independent experiments

between human and rat (ESM Table 4). Analysis of ER stress markers present in the datasets (ESM Table 5) confirmed in primary rat and mouse islet cells the data obtained by RT-PCR in INS-1E and MIN6 cells (ESM Figs 3 and 4). Of particular relevance, cytokines did not inhibit SERCA2B expression in 
human islet cells, while they induced $20 \%$ and $65 \%$ inhibition in mouse islet cells and primary rat beta cells, respectively.

We next examined whether ER stress contributes to cytokine-induced human beta cell apoptosis. For this purpose, human islet or $\mathrm{H} \beta C \mathrm{C}$ cells were exposed to cytokines with or without treatment with TUDCA. In human islet cells, $2 \mathrm{~h}$ pretreatment with TUDCA followed by $48 \mathrm{~h}$ exposure to IL-1 $\beta+$ IFN- $\gamma$ or TNF- $\alpha+$ IFN- $\gamma$ combined with the chemical chaperone nearly completely prevented cytokine-induced apoptosis (Fig. $4 \mathrm{a}, \mathrm{b}$ ). TUDCA pre-exposure ( $24 \mathrm{~h}$ ) followed by $24 \mathrm{~h}$ culture of $\mathrm{H} \beta C L$ cells in the presence of two or three cytokines plus TUDCA also decreased cytokine-induced apoptosis (Fig. 4c, d); a shorter TUDCA pre-exposure time $(2 \mathrm{~h})$ failed to protect these cells from cytokine-induced cell death (Fig. 4e, f). These findings were confirmed by an independent series of experiments using a previously tested siRNA targeting CHOP (also known as DDIT3) [14] (ESM Fig. 7). This siRNA reduced cytokine-induced $C H O P$ expression by
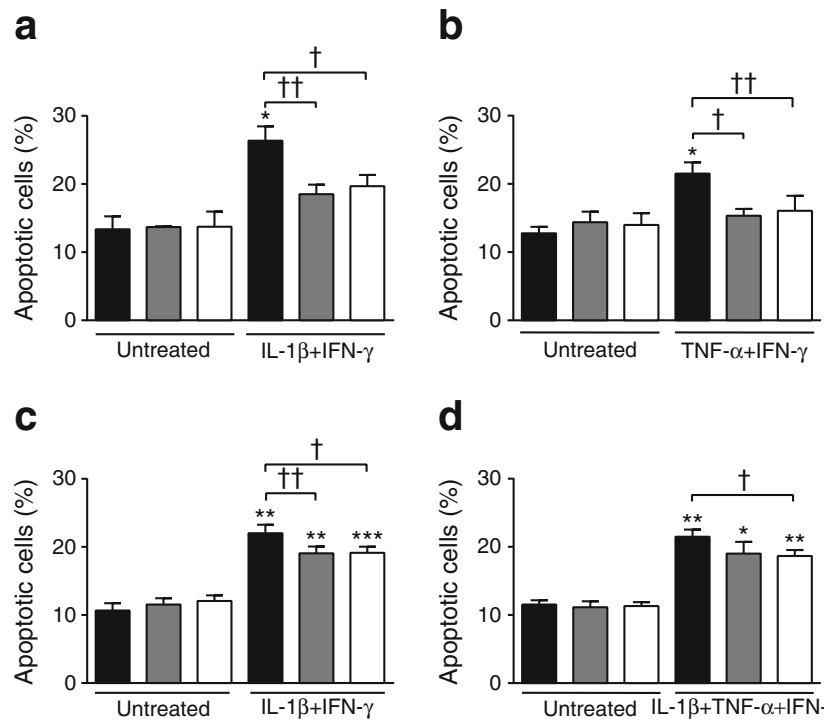

d
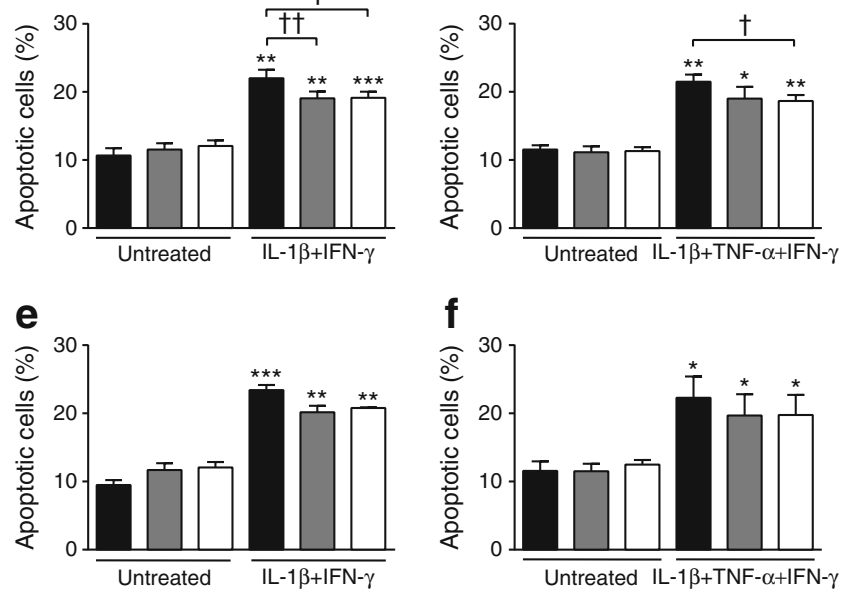

Fig. 4 The chemical chaperone TUDCA protects human islet cells and $\mathrm{H} \beta \mathrm{CL}$ cells against cytokine-induced apoptosis. Human islet cells (a, b) and $\mathrm{H} \beta \mathrm{CL}$ cells $(\mathbf{c}-\mathbf{f})$, were left untreated (black bars) or pre-treated with $62 \mu \mathrm{mol} / 1$ (grey bars) and $125 \mu \mathrm{mol} / 1$ (white bars) of TUDCA for $2 \mathrm{~h} \mathrm{(a,}$ $\mathbf{b}, \mathbf{e}, \mathbf{f})$ or $24 \mathrm{~h}(\mathbf{c}, \mathbf{d})$. Cells were then exposed to cytokines as indicated, alone or in combination with TUDCA. Apoptosis was evaluated after $48 \mathrm{~h}(\mathbf{a}, \mathbf{b}, \mathbf{e}, \mathbf{f})$ or $24 \mathrm{~h}(\mathbf{c}, \mathbf{d})$ of treatment. ${ }^{*} p<0.05,{ }^{* *} p<0.01$ and *** $p<0.001$ vs untreated without TUDCA; ${ }^{\dagger} p<0.05$ and ${ }^{\dagger \dagger} p<0.01$ as indicated by the bars; one-way ANOVA followed by Student's paired $t$ test with Bonferroni correction. Data shown are means \pm SEM of four to five independent experiments
$60 \%$ (ESM Fig. 7a) and partially protected $\mathrm{H} \beta \mathrm{CL}$ cells against cytokine-induced apoptosis (ESM Fig. 7b).

We next examined the downstream mechanisms by which cytokines and ER stress contribute to human islet apoptosis. Cytokines induced a biphasic JNK activation in H $\beta C L$ cells, with peaks at $0.5 \mathrm{~h}$ and $8 \mathrm{~h}$ (Fig. 5a). As well as JNK activation, a major cellular outcome resulting from cytokine exposure is the reduction of AKT activation [21]. The phosphorylation of AKT, however, did not change in cytokine-treated $\mathrm{H} \beta \mathrm{CL}$ cells at any of the time points investigated (ESM Fig. $8 \mathrm{a}, \mathrm{b}$ ). Cytokines also induced activation of IRE1 $\alpha$, which was more marked at $8-16$ h (Fig. 5b). PhosphoIRE $1 \alpha$ was already increased after $0.5 \mathrm{~h}$ in $\mathrm{H} \beta \mathrm{CL}$ cells exposed to IL-1 $\beta+$ IFN- $\gamma$ (ESM Fig. 9a). Knockdown of IRE1 $\alpha$ with three independent siRNAs (ESM Fig. 9b-g) decreases JNK phosphorylation by $\sim 40 \%$ (ESM Fig. 9 b, d, e, g) in $\mathrm{H} \beta \mathrm{CL}$ cells after $0.5 \mathrm{~h}$ and $8 \mathrm{~h}$ of IL- $1 \beta+\mathrm{IFN}-\gamma$ treatment (ESM Fig. 9b-g), suggesting that the IRE $1 \alpha$ pathway contributes to both early and late JNK activation in cytokine-exposed human beta cells [19]. Two independent siRNAs were used to suppress $J N K 1$ (also known as MAPK8) in $\mathrm{H} \beta \mathrm{CL}$ cells, achieving $>60 \%$ inhibition of JNK1 expression (Fig. 5c, d) and a $60 \%$ inhibition of c-JUN phosphorylation, the downstream target of JNK activity (Fig. 5c, e). Suppression of JNK1 partially protected the $\mathrm{H} \beta C L$ cells against cytokineinduced apoptosis (Fig. 5f), showing a key role of JNK in cytokine toxicity in human beta cells. Interestingly, TUDCA pre-exposure $(24 \mathrm{~h})$ also significantly decreased cytokineinduced JNK phosphorylation in $\mathrm{H} \beta \mathrm{CL}$ cells (Fig. $5 \mathrm{~g}-\mathrm{h}$ ), suggesting that the protective role of TUDCA against cytokine-induced human beta cell apoptosis (Fig. 4) may involve the inhibition of ER-stress-dependent JNK activation and subsequent triggering.

\section{Discussion}

Here, we show that proinflammatory cytokines induce ER stress in human, mouse and rat beta cells by different mechanisms. ER stress is NO dependent in rat, partially NO dependent in mice and NO independent in human beta cells. A global comparison of cytokine-modulated gene expression in human and mouse islets and in FACS-purified rat beta cells confirmed a closer similarity between human and mouse than between human and rat, which is in line with previous observations regarding susceptibility to cytotoxic agents [26]. Finally, we confirmed that ER stress contributes to cytokineinduced human beta cell apoptosis and identified JNK as a crucial downstream effector.

The first indication that ER stress contributes to beta cell death was the observation that a chemical NO donor causes $\mathrm{ER} \mathrm{Ca}^{2+}$ depletion, CHOP induction and apoptosis in mouse MIN6 cells [46]. It was subsequently shown that IL-1 $\beta+$ 
a
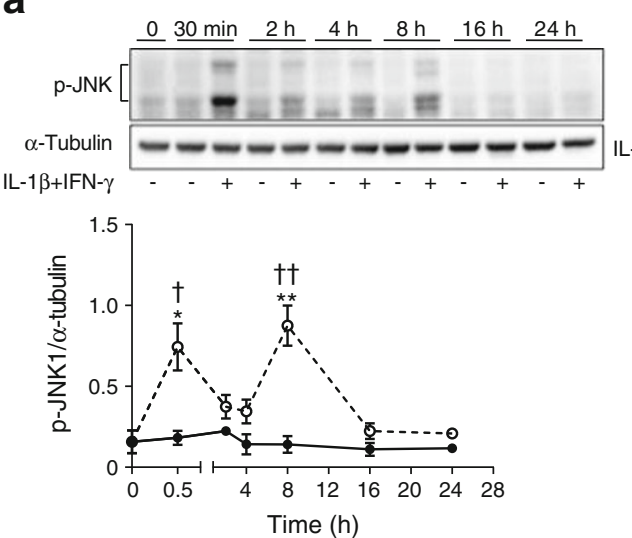

C

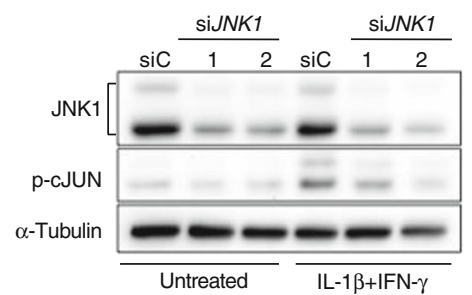

e

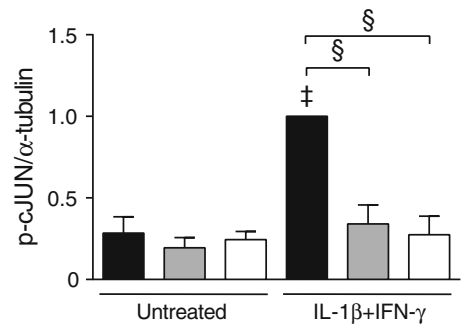

g

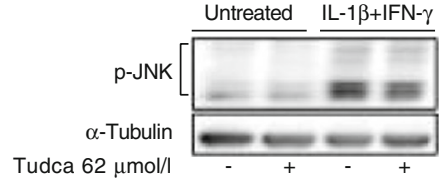

Fig. 5 Cytokine-induced apoptosis in $\mathrm{H} \beta C \mathrm{C}$ cells depends on JNK activation. $(\mathbf{a}, \mathbf{b}) \mathrm{H} \beta \mathrm{CL}$ cells were left untreated (solid lines) or treated with IL- $1 \beta+\mathrm{IFN}-\gamma$ (dashed lines) and proteins were collected at different time points for western blot analysis with antibodies to phospho-JNK (a) and phospho-IRE1 $\alpha$ (b). (c-f) H $\beta C L$ cells were transfected with siC (black bars) or two different siRNAs targeting $J N K 1$ (1, grey bars and 2, white bars). After transfection, cells were left untreated or treated with IL-1 $\beta+$ IFN- $\gamma$ for $48 \mathrm{~h}$ and proteins were collected for western blot analysis with JNK1 and phospho-cJUN antibodies $(\mathbf{c}-\mathbf{e})$. Apoptosis was also evaluated in the same samples (f). H $\beta C L$ cells were left untreated (black bars, $\mathbf{h}$ ) or pre-treated with $62 \mu \mathrm{mol} / 1$ TUDCA for $24 \mathrm{~h}$ (grey bars, h) and then treated for $8 \mathrm{~h}$ with IL- $1 \beta+\mathrm{IFN}-\gamma$ alone or in combination with TUDCA

IFN- $\gamma$ causes severe ER $\mathrm{Ca}^{2+}$ depletion, UPR induction and apoptosis in rat beta cells and INS-1E cells via inhibition of SERCA2B secondary to NO production [11]. On the other b
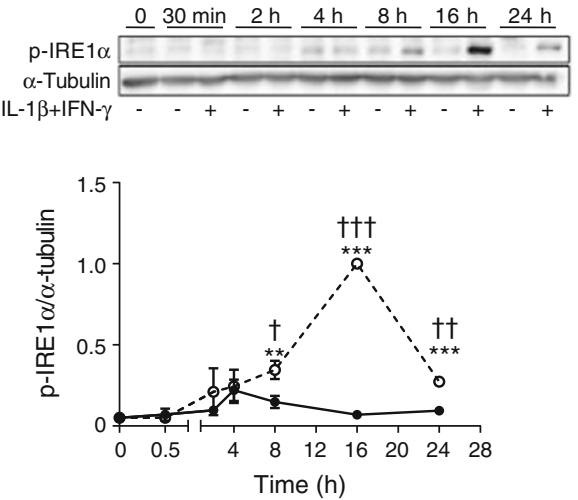

d

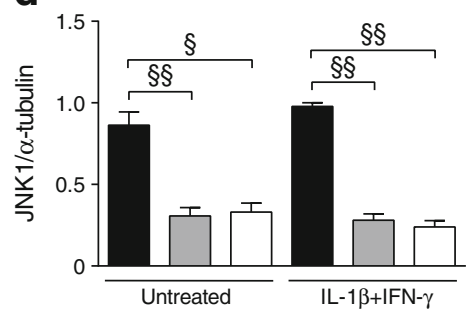

f

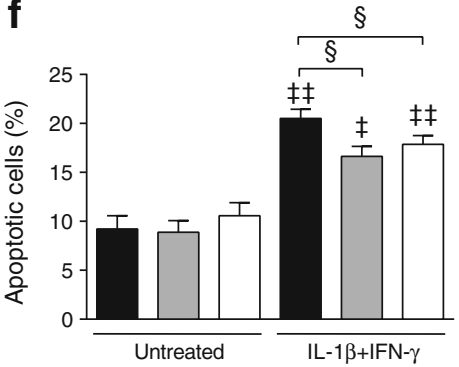

h

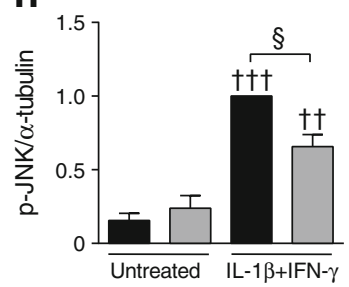

$(\mathbf{g}, \mathbf{h})$. Proteins were collected for western blot analysis with phosphoJNK antibody $(\mathbf{g}, \mathbf{h})$. One representative blot of $n=3-4$ is shown in $(\mathbf{a}-\mathbf{c}$, g) and the densitometric measurements are shown in $(\mathbf{a}, \mathbf{b}, \mathbf{d}, \mathbf{e}, \mathbf{h})$. Expression of $\alpha$-tubulin was used as control for protein loading $(\mathbf{a}-\mathbf{c}, \mathbf{g})$ and the data were normalised by the highest value. ${ }^{*} p<0.05,{ }^{* *} p<0.01$ and $* * * p<0.001$ vs untreated $0 \mathrm{~h} ;{ }^{\dagger} p<0.05,{ }^{\dagger \dagger} p<0.01$ and ${ }^{\dagger \dagger} p<0.001$ IL- $1 \beta+\mathrm{IFN}-\gamma$ vs untreated in each time point $(\mathbf{a}, \mathbf{b}, \mathbf{h}) ;{ }^{\star} p<0.05$ and ${ }^{\sharp \dagger} p<0.01$ vs siC untreated; ${ }^{\S} p<0.05$ and ${ }^{\S \S} p<0.01$ as indicated by the bars $(\mathbf{d}-\mathbf{h})$; one-way ANOVA followed by Student's paired $t$ test with Bonferroni correction. Data shown are means \pm SEM of three to four independent experiments

hand, IL- $1 \beta+$ TNF- $\alpha+$ IFN $-\gamma$ downregulates SERCA2B and induces XBP1 splicing and PERK/eIF2 $\alpha$ phosphorylation in mouse islets and MIN6 cells, to a large extent independently 
of NO production in the time period studied [12]. In human islets TNF- $\alpha+$ IFN- $\gamma$ induces a more marked activation of the ER stress response [14], in spite of the fact that IL- $1 \beta+$ IFN- $\gamma$ induces a nearly tenfold higher increase in NO production [22, 47]. These conflicting observations caused confusion in the field, as it was not clear whether they were due to species differences or other reasons. To clarify this issue, we measured NO production, apoptosis and indicators associated with ER stress in rat, mouse and human beta cell models after cytokine treatment in the presence or absence of the chemical NO inhibitor L-NMMA.

The results in the rat INS-1E cells confirmed the major role for NO in cytokine-mediated apoptosis and ER stress induction [11]. The data obtained in the mouse MIN6 cells confirmed a mostly NO-independent induction of ER stress markers [12]. Finally, NO inhibition did not prevent cytokine-induced ER stress and apoptosis in human islet cells, confirming previous observations regarding the lack of a role for NO in human beta cell apoptosis [22, 48]. BIP was the only ER stress marker with significantly decreased expression after inhibition of NO formation. The expression of BIP is crucial for cell defence against ER stress [40, 41]. BIP decrease may thus explain the observed increase in IL-1 $\beta+$ TNF- $\alpha+$ IFN- $\gamma$-induced human islet cell death when NO formation is inhibited. As there was no cytokine-mediated iNOS induction in the $\mathrm{H} \beta C L$ cells, it is possible that the observed tenfold increase in $\mathrm{NO}$ generation by human islets exposed to cytokines does not originate from beta cells, but from other cell types present in isolated human islets, such as ductal cells [49]. The nature of the mechanisms leading to cytokineinduced ER stress in human beta cells remains unclear, but it may be related to the early and major cytokine-induced insulin increase [22], effects on other $\mathrm{Ca}^{2+}$ pumps besides SERC $\mathrm{A} 2 \mathrm{~B}$, massive upregulation of MHC class I expression and delayed proinsulin processing.

As the induction of ER stress in human islets was less marked than in the rodent models, this raised questions about whether ER stress is indeed important for cytokine-induced apoptosis in human beta cells and, if it is, the nature of the mechanisms involved. To test this, human islet cells or $\mathrm{H} \beta \mathrm{CL}$ cells were exposed to cytokines in the presence of the chemical chaperone TUDCA, previously shown to alleviate ER stress and protect rodent islet cells against cytokine-induced ER stress [9]. The significant protection against cytokinedependent human beta cell apoptosis with TUDCA and the small, although significant, protection after blocking the ER-stress-induced pro-apoptotic transcription factor CHOP support the contribution of ER stress in this process. In a final series of experiments we identified JNK activation as a downstream mechanism leading to human beta cell apoptosis, which is in line with previous observations in rodent beta cells $[50,51]$. Interestingly, TUDCA significantly decreased cytokine-induced JNK activation, providing a mechanistic explanation for the protective effect of this chemical chaperone against cytokine-induced human beta cell apoptosis. During ER stress, IRE $1 \alpha$ triggers JNK phosphorylation through the adaptor protein TNF receptor-associated factor 2 (TRAF2) [52]. The concomitant activation of both JNK and IRE $1 \alpha$ after cytokine exposure in the $\mathrm{H} \beta \mathrm{CL}$ cells (Fig. 5a, b), the decrease in JNK phosphorylation after IRE1 $\alpha$ knockdown (ESM Fig. 9) and the modulation of IRE1 $\alpha /$ JNK pathway by cytokine-induced IRE1 $\alpha$-binding proteins [19] suggest that the IRE $1 \alpha / \mathrm{JNK}$ pathway plays a key role in cytokineinduced apoptosis in human beta cells. This indicates that pathological JNK activation, through IRE1 $\alpha$ or other pathways, may be an interesting target for the prevention of beta cell death in type 1 diabetes.

Acknowledgements We thank: A. Musuaya, M. Pangerl, S. Mertens and R. Lemma for excellent technical support; and Drs G. Bottu and J.-V. Turatsinze for the bioinformatics support. We are grateful to the Flow Cytometry Facility of the Erasmus Campus of the ULB and C. Dubois for the cell sorting.

Funding This work was supported by grants from the JDRF International (grant number 17-2013-515 to DLE, 17-2012-346 to GSH and 5-CDA-2014-184-A-N to FE), European Union (projects NAMIT and BetaBat, in the Framework Programme 7 of the European Community), Actions de Recherche Concertée de la Communauté Française (ARC) and the Fonds National de la Recherche Scientifique (FNRS), Belgium to DLE. TRN is a recipient of a PhD scholarship from the São Paulo Research Foundation (FAPESP), Brazil and FAG of a postdoctoral fellowship of the FNRS, Belgium.

Duality of interest The authors declare that there is no duality of interest associated with this manuscript.

Contribution statement DLE, FB, TRN, ML, JB, IM, FE and GSH contributed to the study concept and design. FB, TRN, JB, IM, MI-E, FAG, $\mathrm{OV}, \mathrm{MB}, \mathrm{JMO}$ and $\mathrm{MC}$ contributed to the acquisition and interpretation of the data. FB, TRN, ML, JB, IM, FE, GSH, PM and DLE analysed the data. FB, TRN, JB, IM, MIE, FAG, OV, MB, JMO, MC, FE, GSH, PM and DLE contributed reagents/materials/analytical tools. DLE, FB and ML wrote the paper. DLE is responsible for the integrity of the work as a whole. All authors revised the article and approved the final version to be published.

\section{References}

1. Eizirik DL, Colli ML, Ortis F (2009) The role of inflammation in insulitis and beta-cell loss in type 1 diabetes. Nat Rev Endocrinol 5: 219-226

2. Eizirik DL, Cardozo AK, Cnop M (2008) The role for endoplasmic reticulum stress in diabetes mellitus. Endocr Rev 29:42-61

3. Ron D, Walter P (2007) Signal integration in the endoplasmic reticulum unfolded protein response. Nat Rev Mol Cell Biol 8: 519-529

4. Eizirik DL, Cnop M (2010) ER stress in pancreatic beta-cells: the thin red line between adaptation and failure. Sci Signal 3:e7

5. Walter P, Ron D (2011) The unfolded protein response: from stress pathway to homeostatic regulation. Science 334:1081-1086 
6. Fonseca SG, Gromada J, Urano F (2011) Endoplasmic reticulum stress and pancreatic beta-cell death. Trends Endocrinol Metab 22: 266-274

7. Gurzov EN, Eizirik DL (2011) Bcl-2 proteins in diabetes: mitochondrial pathways of beta-cell death and dysfunction. Trends Cell Biol 21:424-431

8. Tersey SA, Nishiki Y, Templin AT et al (2012) Islet beta-cell endoplasmic reticulum stress precedes the onset of type 1 diabetes in the nonobese diabetic mouse model. Diabetes 61:818-827

9. Engin F, Yermalovich A, Nguyen T et al (2013) Restoration of the unfolded protein response in pancreatic $\beta$ cells protects mice against type 1 diabetes. Sci Transl Med 5:211ra156

10. Marhfour I, Lopez XM, Lefkaditis D et al (2012) Expression of endoplasmic reticulum stress markers in the islets of patients with type 1 diabetes. Diabetologia 55:2417-2420

11. Cardozo AK, Ortis F, Storling J et al (2005) Cytokines downregulate the sarcoendoplasmic reticulum pump $\mathrm{Ca} 2+$ ATPase $2 \mathrm{~b}$ and deplete endoplasmic reticulum $\mathrm{Ca} 2+$, leading to induction of endoplasmic reticulum stress in pancreatic beta-cells. Diabetes 54: 452-461

12. Chan JY, Cooney GJ, Biden TJ, Laybutt DR (2011) Differential regulation of adaptive and apoptotic unfolded protein response signalling by cytokine-induced nitric oxide production in mouse pancreatic beta-cells. Diabetologia 54:1766-1776

13. Engin F, Hotamisligil GS (2010) Restoring endoplasmic reticulum function by chemical chaperones: an emerging therapeutic approach for metabolic diseases. Diabetes Obes Metab 12(Suppl 2): $108-115$

14. Allagnat F, Fukaya M, Nogueira TC et al (2012) C/EBP homologous protein contributes to cytokine-induced pro-inflammatory responses and apoptosis in beta-cells. Cell Death Differ 19: 1836-1846

15. Marchetti P, Bugliani M, Lupi R et al (2007) The endoplasmic reticulum in pancreatic beta-cells of type 2 diabetes patients. Diabetologia 50:2486-2494

16. Moore F, Colli ML, Cnop M et al (2009) PTPN2, a candidate gene for type 1 diabetes, modulates interferon-gamma-induced pancreatic beta-cell apoptosis. Diabetes 58:1283-1291

17. Eizirik DL, Sammeth M, Bouckenooghe T et al (2012) The human pancreatic islet transcriptome: expression of candidate genes for type 1 diabetes and the impact of pro-inflammatory cytokines. PLoS Genet 8:e1002552

18. Ravassard P, Hazhouz Y, Pechberty S et al (2011) A genetically engineered human pancreatic beta-cell line exhibiting glucoseinducible insulin secretion. J Clin Invest 121:3589-3597

19. Brozzi F, Gerlo S, Grieco FA et al (2014) A combined "omics" approach identifies NMI as a novel cytokine-induced regulator of IRE1alpha and JNK in pancreatic beta-cells. J Biol Chem 289: 20677-20693

20. Asfari M, Janjic D, Meda P, Li G, Halban PA, Wollheim CB (1992) Establishment of 2-mercaptoethanol-dependent differentiated insulin-secreting cell lines. Endocrinology 130:167-178

21. Storling J, Binzer J, Andersson AK et al (2005) Nitric oxide contributes to cytokine-induced apoptosis in pancreatic beta-cells via potentiation of JNK activity and inhibition of Akt. Diabetologia 48: 2039-2050

22. Eizirik DL, Sandler S, Welsh N et al (1994) Cytokines suppress human islet function irrespective of their effects on nitric oxide generation. J Clin Invest 93:1968-1974

23. Eizirik DL, Mandrup-Poulsen T (2001) A choice of death-the signal-transduction of immune-mediated beta-cell apoptosis. Diabetologia 44:2115-2133

24. Kutlu B, Cardozo AK, Darville MI et al (2003) Discovery of gene networks regulating cytokine-induced dysfunction and apoptosis in insulin-producing INS-1 cells. Diabetes 52:2701-2719
25. Ortis F, Cardozo AK, Crispim D, Storling J, Mandrup-Poulsen T, Eizirik DL (2006) Cytokine-induced proapoptotic gene expression in insulin-producing cells is related to rapid, sustained, and nonoscillatory nuclear factor-kappaB activation. Mol Endocrinol 20:1867-1879

26. Eizirik DL, Pipeleers DG, Ling Z, Welsh N, Hellerstrom C, Andersson A (1994) Major species differences between humans and rodents in the susceptibility to pancreatic beta-cell injury. Proc Natl Acad Sci U S A 91:9253-9256

27. Schulz K, Kerber S, Kelm M (1999) Reevaluation of the Griess method for determining $\mathrm{NO} / \mathrm{NO} 2-$ in aqueous and proteincontaining samples. Nitric Oxide 3:225-234

28. Green LC, Wagner DA, Glogowski J, Skipper PL, Wishnok JS, Tannenbaum SR (1982) Analysis of nitrate, nitrite, and [15N]nitrate in biological fluids. Anal Biochem 126:131-138

29. Moore F, Cunha DA, Mulder H, Eizirik DL (2012) Use of RNA interference to investigate cytokine signal transduction in pancreatic beta-cells. Methods Mol Biol 820:179-194

30. Moore F, Santin I, Nogueira TC et al (2012) The transcription factor C/EBP delta has anti-apoptotic and anti-inflammatory roles in pancreatic beta-cells. PLoS One 7:e31062

31. Miani M, Barthson J, Colli ML, Brozzi F, Cnop M, Eizirik DL (2013) Endoplasmic reticulum stress sensitizes pancreatic betacells to interleukin-1 $\beta$-induced apoptosis via Bim/A1 imbalance. Cell Death Dis 4:e701

32. Cunha DA, Hekerman P, Ladriere L et al (2008) Initiation and execution of lipotoxic ER stress in pancreatic beta-cells. J Cell Sci 121:2308-2318

33. Hoorens A, Van de CM, Kloppel G, Pipeleers D (1996) Glucose promotes survival of rat pancreatic beta cells by activating synthesis of proteins which suppress a constitutive apoptotic program. J Clin Invest 98:1568-1574

34. Rasschaert J, Ladriere L, Urbain M et al (2005) Toll-like receptor 3 and STAT- 1 contribute to double-stranded RNA+ interferongamma-induced apoptosis in primary pancreatic beta-cells. J Biol Chem 280:33984-33991

35. Chen MC, Proost P, Gysemans C, Mathieu C, Eizirik DL (2001) Monocyte chemoattractant protein-1 is expressed in pancreatic islets from prediabetic NOD mice and in interleukin-1 $\beta$-exposed human and rat islet cells. Diabetologia 44:325-332

36. Overbergh L, Valckx D, Waer M, Mathieu C (1999) Quantification of murine cytokine mRNAs using real time quantitative reverse transcriptase PCR. Cytokine 11:305-312

37. Cardozo AK, Kruhoffer M, Leeman R, Orntoft T, Eizirik DL (2001) Identification of novel cytokine-induced genes in pancreatic beta-cells by high-density oligonucleotide arrays. Diabetes 50:909-920

38. Roggli E, Gattesco S, Caille D et al (2012) Changes in microRNA expression contribute to pancreatic beta-cell dysfunction in prediabetic NOD mice. Diabetes 61:1742-1751

39. Moore F, Naamane N, Colli ML et al (2011) STAT1 is a master regulator of pancreatic beta-cell apoptosis and islet inflammation. J Biol Chem 286:929-941

40. Shu CW, Sun FC, Cho JH et al (2008) GRP78 and Raf-1 cooperatively confer resistance to endoplasmic reticulum stress-induced apoptosis. J Cell Physiol 215:627-635

41. Cunha DA, Ladriere L, Ortis F et al (2009) Glucagon-like peptide-1 agonists protect pancreatic beta-cells from lipotoxic endoplasmic reticulum stress through upregulation of $\mathrm{BiP}$ and JunB. Diabetes 58:2851-2862

42. Ortis F, Naamane N, Flamez D et al (2010) Cytokines interleukin$1 \beta$ and tumor necrosis factor-alpha regulate different transcriptional and alternative splicing networks in primary beta-cells. Diabetes 59: $358-374$ 
43. Wolden-Kirk H, Rondas D, Bugliani M et al (2014) Discovery of molecular pathways mediating 1,25dihydroxyvitamin D3 protection against cytokine-induced inflammation and damage of human and male mouse islets of Langerhans. Endocrinology 155:736-747

44. Ylipaasto P, Kutlu B, Rasilainen S et al (2005) Global profiling of coxsackievirus- and cytokine-induced gene expression in human pancreatic islets. Diabetologia 48:1510-1522

45. Lopes M, Kutlu B, Miani M et al (2014) Temporal profiling of cytokine-induced genes in pancreatic beta-cells by meta-analysis and network inference. Genomics 103:264-275

46. Oyadomari S, Takeda K, Takiguchi M et al (2001) Nitric oxideinduced apoptosis in pancreatic beta-cells is mediated by the endoplasmic reticulum stress pathway. Proc Natl Acad Sci U S A 98: 10845-10850

47. Hostens K, Pavlovic D, Zambre Y et al (1999) Exposure of human islets to cytokines can result in disproportionately elevated proinsulin release. J Clin Invest 104:67-72
48. Delaney CA, Pavlovic D, Hoorens A, Pipeleers DG, Eizirik DL (1997) Cytokines induce deoxyribonucleic acid strand breaks and apoptosis in human pancreatic islet cells. Endocrinology 138: 2610-2614

49. Pavlovic D, Pavlovic D, Chen MC et al (1999) Contribution of ductal cells to cytokine responses by human pancreatic islets. Diabetes 48:29-33

50. Ammendrup A, Maillard A, Nielsen K et al (2000) The c-Jun amino-terminal kinase pathway is preferentially activated by interleukin-1 and controls apoptosis in differentiating pancreatic beta-cells. Diabetes 49:1468-1476

51. Ortis F, Pirot P, Naamane $\mathrm{N}$ et al (2008) Induction of nuclear factorkappaB and its downstream genes by TNF-alpha and IL- $1 \beta$ has a pro-apoptotic role in pancreatic beta- cells. Diabetologia 51:12131225

52. Urano F, Wang X, Bertolotti A et al (2000) Coupling of stress in the ER to activation of JNK protein kinases by transmembrane protein kinase IRE1. Science 287:664-666 